\title{
THE COSMETIC OUTCOME OF BREAST RECONSTRUCTION: REPRODUCIBILITY OF DIFFERENT METHODS ASSESSED BY DIFFERENT PROFESSIONALS
}

\author{
Resultado estético após reconstrução mamária: reprodutibilidade \\ de diferentes métodos avaliados por diferentes profissionais
}

\author{
Hugo Andrade Bayeh ${ }^{10}$, Regis Resende Paulinelli1 (1), Leonardo Ribeiro Soares ${ }^{1}$ (D), \\ Ana-Carolina Lagos Prates ${ }^{1}$, Pauline Camargo Morais', Izabela Cristina Souza de Albuquerque $\mathbb{1}^{10}$, \\ Aloisio Garcia Souza², Tuanny Roberta Beloti² (1D, Ruffo Freitas-Junior ${ }^{1 *}$ (1)
}

\section{ABSTRACT}

Objective: To compare the reproducibility of different methods for assessing the cosmetic outcome of breast reconstruction, which was assessed by different health professionals. Methods: Photographs of 270 breast cancer patients who had been submitted to breast reconstruction of some type were included. A plastic surgeon, a resident in plastic surgery, two mastologists, two residents in mastology, and two psychologists performed the evaluation. The modified Garbay and Harvard scales and the objective BCCT. core software program were used. Cohen's Kappa and Spearman correlation coefficients were calculated. Results: The mean age of the patients was 55.7 ( \pm 11.1 ) years. Overall, 145 women (53.7\%) underwent partial breast reconstruction and 125 (46.3\%), total breast reconstruction. The mean follow-up time was $63.7 \pm 45.6$ months. By applying the Harvard scale, the interobserver reproducibility among the different professionals was minimal; whereas the Garbay scale had no agreement. The correlations between the BCCT.core software program and the Harvard and modified Garbay scales were moderate. Conclusion: Correlations between both the modified Garbay scale and the Harvard scale and the objective (BCCT.core) test were moderate. There was less interobserver variability with the Harvard scale compared to the modified Garbay scale.

KEYWORDS: breast neoplasms; reconstructive surgical procedures; surgery, plastic.

\section{RESUMO}

Objetivo: Comparar a reprodutibilidade de métodos diferentes de avaliação dos resultados estéticos de cirurgias reconstrutivas da mama, por avaliadores distintos. Métodos: Foram incluídas fotografias de 270 pacientes portadoras de neoplasia da mama que passaram por cirurgias reconstrutivas da mama. As notas da avaliação foram dadas por um cirurgião plástico, um residente em cirurgia plástica, dois mastologistas, dois residentes em mastologia e dois psicólogos. Foram utilizadas as escalas de Harvard e Garbay modificada e a nota objetiva do programa BCCT.core. Foram calculados os índice Kappa de concordância interobservador e de correlação de Spearman. Resultados: A média de idade das pacientes foi de 55,7 anos $( \pm 11,1)$. No geral, $145(53,7 \%)$ mulheres foram submetidas a tratamento conservador com cirurgia oncoplástica e 125 (46,3\%) passaram por mastectomia e reconstrução total.

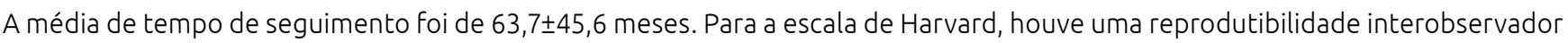
razoável para os diferentes profissionais, enquanto na escala de Garbay, a reprodutibilidade foi pobre entre os profissionais. De forma geral, a nota dada pelo programa BCCT.core correlacionou-se moderadamente com a escala de Harvard e a de Garbay modificada. Conclusão: As escalas de Harvard e de Garbay modificada correlacionam-se igualmente de forma moderada com o teste objetivo (BCCT.core). A escala de Harvard tem menor variabilidade interobservador, se comparada com a escala de Garbay.

PALAVRAS-CHAVE: neoplasias da mama; procedimentos cirúrgicos reconstrutivos; cirurgia plástica.

${ }^{1}$ Program of Mastology, Department of Obstetrics and Gynecology, Teaching Hospital, Universidade Federal de Goiás (UFG) - Goiânia (GO), Brazil. 2Department of Plastic Surgery, Teaching Hospital, UFG - Goiânia (GO), Brazil.

*Corresponding author: ruffojr@terra.com.br

Conflict of interests: nothing to declare.

Received on: 05/04/2019. Accepted on: 06/10/2019 


\section{INTRODUCTION}

Breast-conserving surgery is widely used today in the treatment of locoregional breast cancer ${ }^{1}$. When radical surgery is required, immediate or delayed, breast reconstruction can be performed in a large proportion of cases. The breast reconstruction cosmetic outcome may vary. Its assessment in a standardized manner is difficult ${ }^{2}$. Some methods have been developed to standardize cosmetic evaluation, including the BCCT.core software program ${ }^{3}$, the Garbay ${ }^{4}$ and Harvard scales ${ }^{5-7}$.

Difficulties involved in aesthetic evaluation following breast cancer surgery include the lack of a gold-standard method. Likewise, considerable interobserver variability has been found ${ }^{6}$, and there is a lack of agreement when the results of evaluation are compared between healthcare professionals and the patients themselves.

BCCT.core is an objective method that was initially developed to standardize and quantify the cosmetic outcome of breast-conserving surgery ${ }^{7}$. It was later validated for the breast reconstruction evaluation following mastectomy ${ }^{8}$. This software program performs a photographic evaluation of the breasts by analyzing different parameters related to symmetry, scarring, and skin coloring ${ }^{3,7}$. BCCT.core is currently the most commonly used method for the aesthetic evaluation of breast cancer patients. Its results are classified as excellent, good, fair, or poor ${ }^{9}$.

The method developed and modified by Garbay et al. ${ }^{4}$ takes the volume, shape, and placement of the breast into consideration, as well as the location of the inframammary fold and the final scar appearance. One advantage of this scale is the number of analyzed parameters, which may result in a more complete evaluation of the outcome ${ }^{10}$. The Harvard scale, on the other hand, evaluates only postoperative symmetry and classifies it in four categories according to the degree of distortion of the operated breast in relation to the normal breast ${ }^{11}$.

Few studies have been published on the reproducibility of different methods of evaluating cosmetic outcome in the same population, from the patient's point of view and in the opinion of a multidisciplinary healthcare team ${ }^{10,12}$. The present study aimed to compare the reproducibility of three methods used to evaluate the breast reconstruction cosmetic outcome according to the type of evaluator.

\section{METHODS}

This was a retrospective cohort study conducted in a private clinic and in a tertiary referral hospital for the treatment of breast pathologies. Frontal photographs of 270 patients who had completed six months since radiotherapy (or since having surgery if radiotherapy was not required) were included in the study. All the patients had been diagnosed with breast cancer and submitted to breast-conserving surgery or radical mastectomy, with partial or total breast reconstruction. Data were collected between January 2015 and September 2016, when the patients returned for a scheduled follow-up visit. Patients with local recurrences that could negatively affect the cosmetic outcome were excluded from the study, as were those undergoing reconstruction with the use of a temporary tissue expander who had not exchanged it yet for a permanent breast implant.

\section{Evaluation methods}

Evaluation was conducted by members of a multidisciplinary team, consisting of a plastic surgeon and a plastic surgery resident, two breast specialists trained in breast reconstruction, two medical residents specializing in breast disease, and two psychologists. The analyses were performed blindly and randomly, without any type of patient or assistant team's identification. The Harvard scale ${ }^{5-7}$, the modified Garbay scale ${ }^{4}$ and the score given by the BCCT.core objective software tool were compared (Chart 1 and Figure 1).

\section{Statistical analysis}

The SPSS statistical software program and the <www.statstodo. com $>$ internet page were used for the statistical analysis. Measures of central tendency and percentages were calculated, as well as Cohen's Kappa coefficient to measure interobserver agreement and Spearman's rank-order correlation (rho). The Kappa coefficient ranges from 0.0 to 1.0, and agreement was classified as:

- between 0.01 and 0.20: slight;

- between 0.21 and 0.40: fair;

- between 0.41 and 0.60: moderate;

- between 0.61 and 0.80: substantial;

- $\quad$ between 0.81 and 1.0: almost perfect ${ }^{13,14}$.

Spearman's correlation coefficient $\rho$ ranges from -1 to 1 , and the closer it lies to one of these extremes, the greater the association between the variables.

\section{Ethics approval and consent to participate}

The internal review board of the Teaching Hospital from Universidade Federal de Goiás approved the study protocol (018/2015), and the procedures were conducted in accordance with the principles defined in the Helsinki convention. The participants were volunteers and signed an informed consent form prior to their admission to the study.

\section{RESULTS}

A total of 270 women were included in the study, in which 176 patients $(65.2 \%)$ were from a private clinic and $94(34.8 \%)$ were from a public hospital. Mean time of follow-up was $63.7 \pm 45.6$ months. The mean age of the patients was $55.7 \pm 11$.1 years. Breast cancer was classified as invasive ductal carcinoma in 200 cases $(74.3 \%)$. In 208 cases $(80.9 \%)$, the disease was at an early stage $(0,1$ or 2$)$. Breast-conserving surgery with partial breast reconstruction was 
the treatment of choice in 145 cases (53.7\%). In 144 women (53.3\%), contralateral symmetrization was performed. Reconstruction was immediate in 254 cases (94.1\%) and was performed by a breast specialist in 208 cases (77.9\%). Breast reconstruction consisted of a one-stage surgical procedure in 185 cases (68.5\%). The nippleareola complex was reconstructed in 55 patients (45.8\%) in whom it had been removed. Some type of early or late complication was found in $48 \%$ of the patients. Characteristics of the patients, disease, and treatment are provided in greater details in Table 1.

Interobserver reproducibility with the Harvard scale was fair among different professionals (Kappa=0.27) and poor between plastic surgeons and psychologists (Kappa=0.17); however, the difference was not statistically significant (Table 2). Reproducibility with the Garbay scale was equally poor among the different professionals (Kappa $=0.12$ ).

In general, correlation between the score provided by the BCCT.core software program and Harvard (Rho BCCT 0.39 to 0.61) and modified Garbay (Rho BCCT 0.37 to 0.58 ) scores was moderate, with no statistically significant difference between them. The plastic surgery resident (42.2\%) and the plastic surgeon $(15.6 \%)$ were more likely to rate the outcome as poor compared to the other professionals (range 3.0-14.1\%) and to the BCCT.core program (6.7\%). The BCCT.core program was more likely to rate the results as good and more likely to avoid the extremes (poor and excellent), as seen in Tables 3 and 4.

\section{DISCUSSION}

Evaluation of the breast reconstruction cosmetic outcome is controversial, not only with respect to the selection of optimal methods, but also regarding the interpretation of the obtained results. Nevertheless, these results need to be validated in different population subgroups. This is the largest study to focus specifically on the methodology of evaluation. In addition, it aimed at comparing the Harvard scale, the modified Garbay scale, and the BCCT.core software program.

The greater the number of involved parameters and the more complex the model of evaluation, the poorer a method

Chart 1. Chart showing the modified Garbay ${ }^{10}$ and Harvard scales ${ }^{5-7}$ for the breast reconstruction cosmetic outcome.

\begin{tabular}{|c|c|c|c|}
\hline \multicolumn{4}{|c|}{ Garbay scale } \\
\hline Parameter / Score & 0 points & 1 point & 2 points \\
\hline Breast volume & $\begin{array}{l}\text { Marked discrepancy relative to } \\
\text { contralateral side }\end{array}$ & $\begin{array}{l}\text { Mild discrepancy relative to } \\
\text { contralateral side }\end{array}$ & Symmetrical volume \\
\hline Breast shape & $\begin{array}{c}\text { Marked contour deformity or shape } \\
\text { asymmetry }\end{array}$ & $\begin{array}{l}\text { Mild contour deformity or shape } \\
\text { asymmetry }\end{array}$ & Natural or symmetrical contour \\
\hline Breast placement & Marked displacement & Mild displacement & $\begin{array}{l}\text { Symmetrical and aesthetic } \\
\text { placement }\end{array}$ \\
\hline Inframammary fold & Poorly defined / unidentified & Defined, but asymmetrical & Defined and symmetrical \\
\hline Breast scars & Poor (hypertrophy, contracture) & $\begin{array}{l}\text { Fair (wide scars, poor color match, } \\
\text { but no hypertrophy or contracture) }\end{array}$ & Good (thin scars, good color match) \\
\hline \multicolumn{4}{|c|}{ Harvard scale } \\
\hline Category & \multicolumn{3}{|c|}{ Results } \\
\hline Excellent & \multicolumn{3}{|c|}{ Treated breast nearly identical to untreated breast } \\
\hline Good & \multicolumn{3}{|c|}{ Treated breast slightly different from untreated breast } \\
\hline Fair & \multicolumn{3}{|c|}{ Treated breast clearly different from untreated breast, but not seriously distorted } \\
\hline Poor & \multicolumn{3}{|c|}{ Treated breast seriously distorted } \\
\hline
\end{tabular}

\section{Excellent}

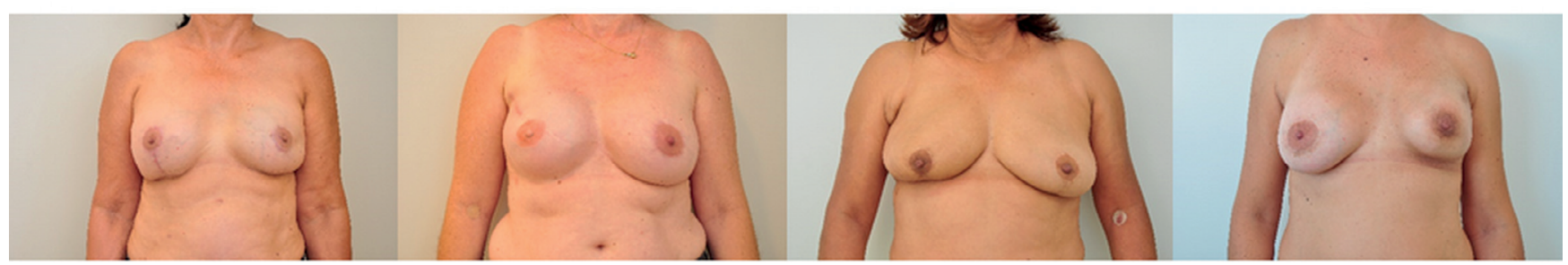

Figure 1. Examples of photograph classification according to evaluations performed with the BCCT.core computer software program regarding the breast reconstruction cosmetic outcome. 
reproducibility tends to be ${ }^{15}$. This statement is also valid for the present study, in which the Harvard scale, which is the simplest, also proved to be the most reproducible among healthcare professionals. Thus, in view of the inherent limitations of the evaluation methods and absence of a gold-standard method to evaluate the breast reconstruction cosmetic outcome, it may be advisable to perform the evaluation using more than one method and with more than one professional.

Correlations between the objective test (BCCT.core) and both the modified Garbay scale and the Harvard scale were equally moderate. The lowest interobserver variability was found with the Harvard score, because it is simpler, with fewer categories. Despite the poor reproducibility between the used scales, the correlation between both scales and the objective (BCCT.core) evaluation was similar and either can be used according to the observer's preference.

Patients tend to be more satisfied with the outcome of breast reconstruction compared to observers from the healthcare professions, with this rater role being generally played by surgeon $\mathrm{s}^{16,17}$. This is expected, since both the BCCT.core program and the Harvard and modified Garbay scales concentrate on symmetry. Thus, symmetry does not always coincide with the beauty concept. Therefore, patients could have symmetrical breasts but be dissatisfied with their appearance and, inversely, despite a certain degree of asymmetry, they may consider their breasts more attractive than they were before the cancer treatment, for

Table 1. Descriptive data on characteristics of the patients, the tumors, and the treatment provided.

\begin{tabular}{|c|c|c|c|c|c|c|c|c|}
\hline & Mean & SD & $\mathbf{n}$ & $\%$ & & Mean & $\mathbf{n}$ & $\%$ \\
\hline \multicolumn{5}{|l|}{ Patients' characteristics } & \multicolumn{4}{|l|}{ Follow-up (months) 63.745 .6} \\
\hline Age (years) & 55.7 & 11.2 & & & Local recurrence & & 9 & 3.3 \\
\hline Body mass index & 26.3 & 4.15 & & & Metastases & & 6 & 2.2 \\
\hline \multicolumn{3}{|l|}{ Smoker } & 13 & 40 & \multicolumn{4}{|l|}{ Treatment characteristics } \\
\hline \multirow{2}{*}{\multicolumn{3}{|c|}{ Former smoker }} & & & \multicolumn{4}{|l|}{ Reconstruction } \\
\hline & & & 31 & 11.7 & Partial & & 145 & 53.7 \\
\hline \multicolumn{3}{|l|}{ Diabetic } & 25 & 9.3 & Total & & 125 & 46.3 \\
\hline \multicolumn{3}{|l|}{ Hypertensive } & 97 & 36.5 & Immediate & & 254 & 94.1 \\
\hline \multicolumn{3}{|l|}{ Previous breast surgery } & 65 & 27.4 & Delayed & & 16 & 5.9 \\
\hline \multicolumn{5}{|l|}{ Disease characteristics } & \multicolumn{2}{|l|}{ Contralateral symmetrization } & 132 & 48.9 \\
\hline Clinical size of the tumor (mm) & 34.5 & 23.5 & & & \multicolumn{2}{|c|}{$\begin{array}{l}\text { Reconstruction of the nipple-areola complex } \\
\text { (when removed) }\end{array}$} & 55 & 45.8 \\
\hline \multicolumn{5}{|l|}{ Clinical staging } & \multicolumn{4}{|l|}{ Number of surgeries } \\
\hline \multicolumn{3}{|l|}{0} & 7 & 2.7 & \multicolumn{2}{|l|}{1} & 185 & 68.5 \\
\hline \multicolumn{3}{|l|}{1} & 81 & 31.5 & \multicolumn{2}{|l|}{2} & 51 & 18.9 \\
\hline \multicolumn{3}{|l|}{ II } & 120 & 46.7 & \multicolumn{2}{|l|}{$\geq 3$} & 34 & 12.6 \\
\hline \multicolumn{3}{|l|}{ III } & 46 & 17.9 & \multicolumn{4}{|l|}{ Type of reconstruction } \\
\hline \multirow{2}{*}{\multicolumn{3}{|c|}{ IV }} & 3 & 1.2 & \multicolumn{2}{|l|}{ Oncoplasty } & 134 & 51.1 \\
\hline \multirow{2}{*}{\multicolumn{5}{|c|}{ Histological type }} & \multicolumn{2}{|l|}{ Prosthesis/tissue expander } & 58 & 22.1 \\
\hline & & & & & \multicolumn{2}{|l|}{ Pedicle TRAM flap } & 66 & 25.2 \\
\hline \multicolumn{3}{|l|}{ Invasive ductal carcinoma } & 200 & 74.3 & \multicolumn{2}{|l|}{ Latissimus dorsi flap } & 4 & 1.5 \\
\hline Invasive lobular carcinoma & & & 16 & 5.9 & Surgeon performing breast recc & nstruction & & \\
\hline In situ ductal carcinoma & & & 34 & 12.6 & Breast specialist & & 208 & 77.9 \\
\hline Grade 2 & & & 148 & 59 & Plastic surgeon & & 59 & 22.1 \\
\hline Subtype* & & & & & Chemotherapy & & 176 & 65.2 \\
\hline Luminal A & & & 103 & 45.0 & Hormone therapy & & 216 & 81.2 \\
\hline Luminal B & & & 46 & 20.1 & Trastuzumab & & 32 & 12.1 \\
\hline Luminal B/HER & & & 36 & 157 & Radiotherapy & & 197 & 74.4 \\
\hline & & & & , & Early complication & & 98 & 36.3 \\
\hline HER & & & 18 & 7.9 & Late complication (>2 months) & & 83 & 30.9 \\
\hline Triple negative & & & 26 & 11.3 & Any complication** & & 131 & 48.7 \\
\hline
\end{tabular}

*Luminal A (ER+ and/or PR+, HER2- and Ki67<14\%), Luminal B (ER+ and/or PR+, HER2- and Ki-67 14\%), Luminal B/HER (ER+ and/or PR+, HER2+), HER (ER-, PR- and HER2+), and Triple negative (ER-, PR- and HER2-); **early and/or late complication; TRAM: transverse rectus abdominis myocutaneous; HER2: human epidermal growth-factor receptor 2; ER: estrogen receptor; PR: progesterone receptor; SD: standard deviation. 
Table 2. Interobserver variability according to the Harvard and Garbay scales.

\begin{tabular}{l|c|c} 
Harvard scale & Kappa & $95 \% \mathrm{Cl}$ \\
\hline Among breast specialists & 0.35 & $0.32-0.38$ \\
\hline Among plastic surgeons & 0.27 & $0.19-0.34$ \\
\hline Among psychologists & 0.23 & $0.14-0.32$ \\
\hline $\begin{array}{l}\text { Between breast specialists and plastic } \\
\text { surgeons }\end{array}$ & 0.28 & $0.26-0.29$ \\
\hline Between breast specialists and psychologists & 0.33 & $0.31-0.35$ \\
\hline Between plastic surgeons and psychologists & 0.17 & $0.14-0.20$ \\
\hline Among all professionals & 0.27 & $0.26-0.29$ \\
\hline Garbay scale & Kappa & $95 \% \mathrm{Cl}$ \\
\hline Among breast specialists & 0.13 & $0.11-0.15$ \\
\hline Among plastic surgeons & 0.16 & $0.10-0.22$ \\
\hline Among psychologists & 0.16 & $0.09-0.22$ \\
\hline Between breast specialists and plastic & 0.12 & $0.11-0.13$ \\
\hline surgeons & 0.14 & $0.12-0.15$ \\
\hline Between breast specialists and psychologists & 0.1 & $0.08-0.12$ \\
\hline Between plastic surgeons and psychologists & 0.12 & $0.11-0.13$ \\
\hline Among all professionals & &
\end{tabular}

$\mathrm{Cl}$ : confidence interval of $95 \%$. instance. Hence, new evaluation methods should be developed and investigated to include a broader measure of cosmetic appearance that would better correspond to the patients' expectations and possibly to their degree of satisfaction ${ }^{18}$.

In the majority of previous evaluations made by patients, professionals or the BCCT.core program, outcome was reported as good or excellent, with rates similar to those cited in the literature, depending on the criteria taken into consideration ${ }^{3,6,17}$. In the present study, curiously, the scores awarded by plastic surgeons for the cosmetic outcome were the lowest. Nevertheless, the correlations between their scores and the objective evaluation made by the computer software program were similar to those of other professionals, rendering them equally valid. Conversely, Leonardi et al. found that plastic surgeons and male professionals tended to provide better scores for the outcome ${ }^{6}$. The explanation given by those investigators for this phenomenon was that, in such study, the plastic surgeons were rating their own results and thus tended to be more tolerant and more aware of the difficulties involved in each case. A similar explanation could be given here, since the breast specialists performed over three-quarters of breast reconstructions.

In the present study, more than half of the patients underwent partial breast reconstruction, a procedure usually associated with

Table 3. Correlation between the scores awarded by professionals according to the Harvard Scale and the scores given by the BCCT. core software program.

\begin{tabular}{|c|c|c|c|c|c|c|c|c|c|c|}
\hline \multirow{2}{*}{ Frequency (\%) } & \multicolumn{2}{|c|}{ Poor } & \multicolumn{2}{|c|}{ Fair } & \multicolumn{2}{|c|}{ Good } & \multicolumn{2}{|c|}{ Excellent } & \multirow{2}{*}{ Rho BCCT } & \multirow{2}{*}{$95 \% \mathrm{Cl}$} \\
\hline & $\mathbf{n}$ & $\%$ & $\mathbf{n}$ & $\%$ & n & $\%$ & $\mathbf{n}$ & $\%$ & & \\
\hline Senior breast specialist & 13 & 4.8 & 82 & 30.4 & 115 & 42.6 & 60 & 22.2 & 0.61 & $0.51-0.70$ \\
\hline Junior breast specialist & 38 & 14.1 & 59 & 21.9 & 91 & 33.7 & 82 & 30.4 & 0.49 & $0.39-0.60$ \\
\hline $\begin{array}{l}\text { Second-year resident/ } \\
\text { breast disease program }\end{array}$ & 24 & 8.9 & 97 & 35.9 & 86 & 31.9 & 63 & 23.3 & 0.5 & $0.38-0.59$ \\
\hline $\begin{array}{l}\text { First-year resident/ } \\
\text { breast disease program }\end{array}$ & 25 & 9.3 & 88 & 32.6 & 63 & 23.3 & 94 & 34.8 & 0.42 & $0.32-0.53$ \\
\hline Senior plastic surgeon & 42 & 15.6 & 98 & 36.3 & 80 & 29.6 & 50 & 18.5 & 0.48 & $0.38-0.59$ \\
\hline Plastic surgery resident & 114 & 42.2 & 65 & 24.1 & 68 & 25.2 & 23 & 8.5 & 0.48 & $0.38-0.59$ \\
\hline Senior psychologist & 22 & 8.1 & 74 & 27.4 & 120 & 44.4 & 54 & 20.0 & 0.54 & $0.42-0.63$ \\
\hline Junior psychologist & 8 & 3.0 & 37 & 13.7 & 116 & 43.0 & 109 & 40.4 & 0.39 & $0.29-0.51$ \\
\hline ВССТ.core & 18 & 6.7 & 77 & 28.5 & 144 & 53.3 & 31 & 11.5 & 1 & - \\
\hline
\end{tabular}

$\mathrm{Cl}$ : confidence interval of $95 \%$.

Table 4. Modified Garbay Scale: mean scores and correlation with scores given by the BCCT.core software program.

\begin{tabular}{l|c|c|c|c} 
& \multicolumn{2}{|c|}{ Mean $( \pm \mathrm{SD}) 95 \% \mathrm{Cl}$} & \multicolumn{2}{c}{ Rho BCCT (95\%Cl) } \\
Senior breast specialist & $7.16( \pm 1.93)$ & $6.92-7.39$ & 0.58 & $0.47-0.67$ \\
\hline Junior breast specialist & $7.37 \pm 2.68)$ & $7.05-7.69$ & 0.51 & $0.39-0.60$ \\
\hline Second-year resident/ breast disease program & $7.04( \pm 1.74)$ & $6.83-7.25$ & 0.57 \\
\hline First-year resident/ breast disease program & $7.07( \pm 2.27)$ & $6.8-7.35$ & 0.42 & $0.31-0.53$ \\
\hline Senior plastic surgeon & $5.68( \pm 2.49)$ & $5.38-5.98$ & 0.41 & $0.31-0.53$ \\
\hline Plastic surgery resident & $6.36( \pm 2.08)$ & $6.11-6.61$ & 0.49 & $0.40-0.61$ \\
\hline Senior psychologist & $6.66( \pm 2.34)$ & $6.38-6.94$ & 0.48 & $0.37-0.59$ \\
\hline Junior psychologist & $7.47( \pm 1.71)$ & $7.27-7.67$ & 0.37 & $0.29-0.51$ \\
\hline
\end{tabular}

$\mathrm{Cl}$ : confidence interval; SD: standard deviation. 
lower morbidity, better aesthetic results, greater degree of satisfaction and the same oncologic benefit ${ }^{17,19,20}$. The complication rates can be considered normal, since the criteria established for recording the complications were extremely rigorous and even minimal changes were considered to represent events, including a slightly wider than normal scar, a small seroma, a small depression, or an oil cyst seen at mammography, for example. The complication rates cited in literature vary widely as a result of the different adopted criteria. Most of the studies fail to clearly describe their complication definition and fail to report on the severity of events. Hence, while some authors already consider the presence of subclinical fat necrosis following a transverse rectus abdominis myocutaneous (TRAM) flap procedure to be a complication, others only register a complication when there is flap necrosis with losses exceeding $20 \%^{21-23}$.

Some potential limitations of our study were the retrospective design and the evaluation of results by the same team that operated the patients. However, the analyses were performed blindly and randomly, which reduces the possibility of measurement bias.
Also, patients with different postoperative periods were included, which may have influenced the distribution of results considered to be poor, fair, good or excellent. Finally, the limitations inherent in the photographic registration ${ }^{24}$ may also justify small differences in cosmetic results between different methods and populations.

\section{CONCLUSION}

Correlations between the modified Garbay and the Harvard scales and the objective test (BCCT.core) were equally moderate. Interobserver variability was lower with the Harvard scale. Although scores may vary depending on the observer, all correlations were valid in accordance with the objective test.

\section{ACKNOWLEDGMENTS}

The authors would like to thank Dr. Rosemar Rahal, Dr. LuisFernando Oliveira, Dr. Elisa Bastos, and Professor Márcia Veloso for their constant professional support.

\section{REFERENCES}

1. Freitas-Júnior R, Gagliato DM, Moura Filho JW, Gouveia PA, Rahal RMS, Paulinelli RR, et al. Trends in breast cancer surgery at Brazil's public health system. J Surg Oncol. 2017;115(5):5449. https://doi.org/10.1002/jso.24572

2. Weber WP, Soysal SD, El-Tamer M, Sacchini V, Knauer M, Tausch C, et al. First international consensus conference on standardization of oncoplastic breast conserving surgery. Breast Cancer Res Treat. 2017;165(1):139-49. https://doi. org/10.1007/s10549-017-4314-5

3. Cardoso JS, Cardoso MJ. Towards an intelligent medical system for the aesthetic evaluation of breast cancer conservative treatment. Artif Intell Med. 2007;40(2):115-26. https://doi. org/10.1016/j.artmed.2007.02.007

4. Garbay JR, Rietjens M, Petit JY. Esthetic results of breast reconstruction after amputation for cancer. 323 cases. J Gynecol Obstet Biol Reprod (Paris). 1992;21(4):405-12.

5. Harris JR, Levene MB, Svensson G, Hellman S. Analysis of cosmetic results following primary radiation therapy for stages I and II carcinoma of the breast. Int J Radiat Oncol Biol Phys. 1979;5(2):257-61. https://doi.org/10.1016/0360-3016(79)90729-6

6. Leonardi MC, Garusi C, Santoro L, Dell'Acqua V, Rossetto F, Didier F, et al. Impact of medical discipline and observer gender on cosmetic outcome evaluation in breast reconstruction using transverse rectus abdominis myocutaneous (TRAM) flap and radiotherapy. J Plast Reconstr Aesthet Surg. 2010;63(12):2091-7. https://doi.org/10.1016/j.bjps.2010.02.013

7. Cardoso MJ, Cardoso J, Santos AC, Barros H, Cardoso de Oliveira M. Interobserver agreement and consensus over the esthetic evaluation of conservative treatment for breast cancer. Breast. 2006;15(1):52-7. https://doi.org/10.1016/j. breast.2005.04.013
8. Preuss J, Lester L, Saunders C. BCCT.core - can a computer program be used for the assessment of aesthetic outcome after breast reconstructive surgery? Breast. 2012;21(4):597600. https://doi.org/10.1016/j.breast.2012.05.012

9. Cardoso MJ, Cardoso JS, Oliveira HP, Gouveia P. The breast cancer conservative treatment. Cosmetic results - BCCT. core - Software for objective assessment of esthetic outcome in breast cancer conservative treatment: A narrative review. Comput Methods Programs Biomed. 2016;126:154-9. https:// doi.org/10.1016/j.cmpb.2015.11.010

10. Urban C. Rietjens M (eds.). Oncoplastic and reconstructive breast surgery. Milan: Springer, 2013.

11. Rose MA, Olivotto I, Cady B, Koufman C, Osteen R, Silver B, et al. Conservative surgery and radiation therapy for early breast cancer.Long-term cosmetic results. Arch Surg. 1989;124(2):1537. https://doi.org/10.1001/archsurg.1989.01410020023002

12. Wachter T, Edlinger M, Foerg C, Djedovic G, Mayerl C, Kinzl J, et al. Differences between patients and medical professionals in the evaluation of aesthetic outcome following breast reconstruction with implants. J Plast Reconstr Aesthet Surg. 2014;67(8):1111-7. https://doi.org/10.1016/j.bjps.2014.04.004

13. Landis JR, Koch GG. The measurement of observer agreement for categorical data. Biometrics. 1977;33(1):159-74.

14. Evans JD. Straightforward Statistics for the Behavioral Sciences. Pacific Grove, CA: Brooks/Cole Publishing; 1996.

15. Cardoso MJ, Cardoso J, Amaral N, Azevedo I, Barreau L, Bernardo M, et al. Turning subjective into objective: the BCCT. core software for evaluation of cosmetic results in breast cancer conservative treatment. Breast. 2007;16(5):456-61. https://doi.org/10.1016/j.breast.2007.05.002 
16. Casella D, Di Taranto G, Marcasciano M, Sordi S, Kothari A, Kovacs T, et al. Nipple-sparing bilateral prophylactic mastectomy and immediate reconstruction with TiLoop ${ }^{\circledR}$ Bra mesh in BRCA1/2 mutation carriers: A prospective study of long-term and patient reported outcomes using the BREAST-Q. Breast. 2018;39:8-13. https://doi.org/10.1016/j. breast.2018.02.001

17. Santos G, Urban C, Edelweiss MI, Zucca-Matthes G, de Oliveira VM, Arana GH, et al. Long-Term Comparison of Aesthetical Outcomes After Oncoplastic Surgery and Lumpectomy in Breast Cancer Patients. Ann Surg Oncol. 2015;22(8):2500-8. https://doi.org/10.1245/s10434-0144301-6

18. Ho PJ, Hartman M, Young-Afat DA, Gernaat SAM, Lee SC, Verkooijen HM. Determinants of satisfaction with cosmetic outcome in breast cancer survivors: A cross-sectional study. PLoS One. 2018;13(2):e0193099. https://doi.org/10.1371/ journal.pone.0193099

19. Wijgman DJ, Ten Wolde B, van Groesen NR, Keemers-Gels ME, van den Wildenberg FJ, Strobbe LJ, et al. Short term safety of oncoplastic breast conserving surgery for larger tumors. Eur J Surg Oncol. 2017;43(4):665-71. https://doi. org/10.1016/j.ejso.2016.11.021
20. Ojala K, Meretoja TJ, Leidenius MH. Aesthetic and functional outcome after breast conserving surgery - Comparison between conventional and oncoplastic resection. Eur J Surg Oncol. 2017;43(4):658-64. https://doi.org/10.1016/j.ejso.2016.11.019

21. Olsen MA, Nickel KB, Fox IK, Margenthaler JA, Wallace AE, Fraser VJ. Comparison of Wound Complications After Immediate, Delayed, and Secondary Breast Reconstruction Procedures. JAMA Surg. 2017;152(9):e172338. https://doi. org/10.1001/jamasurg.2017.2338

22. Andrades P, Fix RJ, Danilla S, Howell RE 3rd, Campbell WJ, De la Torre J, et al. Ischemic complications in pedicle, free, and muscle sparing transverse rectus abdominis myocutaneous flaps for breast reconstruction. Ann Plast Surg. 2008;60(5):5627. https://doi.org/10.1097/SAP.0b013e31816fc372

23. Chirappapha P, Somintara O, Lertsithichai P, Kongdan Y, Supsamutchai C, Sukpanich R, et al. Complications and oncologic outcomes of pedicled transverse rectus abdominis myocutaneous flap in breast cancer patients. Gland Surg. 2016;5(4):405-15. https://dx.doi.org/10.21037\%2Fgs.2016.07.01

24. Soares PCM, Pires DM, Medeiros CM. The standardization of photographic records for oncoplastic and breast reconstructive surgery. Mastology. 2017;27(4):352-8. https://dx.doi.org/10.292 89/2594539420170000248 